\title{
St. Thomas Aquinas \\ on Satisfaction, \\ Indulgences, and Crusades
}

ROMANUS CESSARIO, O.P.

In order properly to elucidate the church's doctrine on indulgences, the theologian must study the practice of granting indulgences in the contexts of the satisfaction of Christ and of penitential works undertaken by Christian believers. ${ }^{1}$ In his treatment of indulgences, Thomas Aquinas is concerned to explain how Christ's redemptive sufferings can spiritually benefit the members of the mystical body. Aquinas understands that, through indulgences, the church allots certain spiritual benefits to those who collaborate by one means or another in building up the mystical body. ${ }^{2}$ In his view, then, the theology of indulgences simply develops the general theological axiom that one person can share according to some determined measure in

1. For the historical development of indulgences, see Bernhard Poschmann, Der Ablaß im Licht der Bußgeschichte (Bonn: Peter Hanstein, 1948).

2. For example, Nikolaus Paulus, Indulgences as a Social Factor in the Middle Ages, trans. J. Elliot Ross (New York: Devin-Adair, 1922), illustrates how the church related indulgences to various aspects of ecclesial communion. See the sections entitled "Indulgences for Ecclesiastical and Charitable Objects" and "Indulgences for Socially Useful Temporal Objects." 
the good deeds of another person. To put it differently, as much as Christians ought to pray for and help one another, indulgences are a way of giving concrete expression to the communion of saints.

Aquinas undertakes a broad, multifaceted study. Besides analyzing the nature of indulgences, he also illustrates their connection to the sacrament of reconciliation, defines the proper authorities for granting indulgences, and examines the necessary conditions for gaining an indulgence. ${ }^{3}$ In the course of these discussions, Aquinas gives clear evidence that he appreciates how the thirteenth-century church had made canon law a principal means of establishing the principles of pastoral care. But since his theological project is not restricted simply to questions of jurisprudence and pastoral practice, Aquinas normally discusses such issues, including the canonical aspects of indulgences, within the broader contexts of soteriology and ecclesiology; as a result, his conclusions throw more than historical light on the meaning of an indulgence.

For a complete appreciation of St. Thomas's doctrine, two texts in his theological corpus merit special attention. The principal places where Thomas deals with the theology and practice of granting indulgences include his Scriptum super libros Sententiarum 4.20.1.3-5 and Quaestiones de quolibet 2 8.2. To be sure, the editors of the Supplementum to the Summa theologiae assembled three questions on indulgences, but Thomas himself set aside work on the Summa before he was able to confront the questions within its original framework. ${ }^{4}$ The two ex professo discussions that he did complete belong to different periods in his career; they also represent different literary genres. In his "writings" on the Sentences of Peter Lombard, which Aquinas composed at Paris between 1252 and 1256, we recognize a

3. Peter of Bergamo's tabulation, In Opera Sancti Thomae Aquinatis Index Seu Tabula Aurea Eximii Doctoris (Rome: Editiones Paulinae, n.d.), distributes the thirty subjects related to indulgences under four headings: "In communi," "Ecclesiae," "Agens," "Quibus." The Index Thomisticus shows that the vast majority of this material occurs in Aquinas's Scriptum 4.

4. See Summa theol. suppl. 25, "De indulgentia secundum se"; 26, "De his qui possunt indulgentias facere"; 27, "De his quibus valent indulgentiae." James A. Weisheipl, Friar Thomas d'Aquino, 2d ed., with corrigenda and addenda (Washington, D.C.: The Catholic University of America Press, 1983), p. 362, explains that "the Supplement, intended to complete the Summa, is 'put together with scissors and paste from pieces cut out of Aquinas's writings on the Sentences (especially Bk. 4).'” 
systematic treatment from a young theologian. But Quaestio de quolibet 2 , recorded at Paris around 1270 , gives us an insight into how the seasoned university professor handled the subject in open debate. In addition, the De quolibet 28.2 gives witness to a certain growth and change of theological perspective that, according to the opinion of some scholars, marks Aquinas's thinking during the second half of his academic career. ${ }^{5}$

Although I take into account pertinent material from the earlier treatment in the Scriptum, the text De quolibet 28.2 is the principal focus for this study. I also refer to Aquinas's teaching on merit and satisfaction, especially his mature treatment of those subjects in the Summa theologiae. 6 Still, the brief exposition in De quolibet 2 incorporates many of the basic theological principles that Aquinas considers indispensable for a comprehensive understanding of indulgences. ${ }^{7}$ The crusading indulgences, as we shall see, afford him the occasion for articulating a theory concerning the place that indulgences occupy in the church's sacramental economy.

As a principal element of his analysis, Aquinas employs a traditional metaphor. He speaks about the spiritual treasure chest that contains the good works of Christ and the saints: the thesaurus ecclesiae. ${ }^{8}$ Even if such language presents an unwieldy metaphor for

5. For example, R.-A. Gauthier, "La date du Commentaire de saint Thomas sur l'Ethique à Nicomaque," RTAM 18 (1951): 103, n. 91, argues that during the second Parisian regency, Aquinas was induced to "mitigate the excessive intellectualism that he had earlier displayed." See also Santiago Ramirez, De hominis beatitudine 3 (Madrid: CSIC, 1947), p. 192.

6. See Cessario, The Godly Image: Christ and Salvation in Catholic Thought from Anselm to Aquinas, Studies in Historical Theology 6 (Petersham, Mass.: St. Bede's, 1990), for an interpretation of Aquinas's texts on soteriology and Christian satisfaction.

7. De quolibet 28 contains two articles, each of which treats the forgiveness of sins. The first article asks whether the sin against the Holy Spirit remains unforgiveable. The second carries the title: "Utrum crucesignatus qui moritur antequam iter arripiat transmarinum, plenam habeat peccatorum remissionem?" I have consulted Sandra Edwards's translation, Quodlibetal Questions 1 and 2, Medieval Sources in Translation 27 (Toronto: PIMS, 1983). Edwards gives a general introduction to this literary genre and the issues discussed in the two questions.

8. Carl J. Peter, "The Church's Treasures (Thesauri Ecclesiae) Then and Now," Theological Studies 47 (1986): 251-272, examines the history and contemporary significance of this concept. 
Christ's charity, Thomas nonetheless clearly distances himself from both mercantile views of redemption and physicalist interpretations of grace. In brief, he does not consider indulgences as a spiritual depositand-withdrawal system for building up heavenly merits, as if they were so much interest in a bank account. ${ }^{9}$ Indeed, we can uncover no justification in Aquinas's theology for the well-known abuses of the later Middle Ages, especially the so-called sale of indulgences by professional "pardoners." One might even argue that if Aquinas's theological finesse in treating indulgences had shaped the practice of the church in the sixteenth century, they might not have been one of the issues that provoked Protestant reform. For Aquinas consistently demonstrates that indulgences form an integral part of the church's mission to communicate both the merits of Christ's sacrifice and his satisfaction to believers in the truth of the gospel.

\section{HISTORICAL BACKGROUND: PARIS, 1269-1272}

The historical circumstance that links the granting of indulgences to the church's promotion of the crusades serves as background for De quolibet 2 8.2. Aquinas inquires whether a crusader who dies before setting forth for the Holy Land and thereby escapes the hardships and duress of fighting the infidels actually gains a full remission of his sins. ${ }^{10}$ The church had formally begun the practice of

9. To be sure, we have examples where Aquinas's language lends itself to such an interpretation, as when he suggests in the De quolibet 57.2 that meritorious deeds can remain with us "quasi apud Deum deposita," but the context clearly indicates that the idiom is suggested by the Vulgate, as for example in 2 Timothy 1:12, "Scio enim cui credidi, et certus sum quia potens est depositum meum servare in illum diem."

10. The twelfth-century Latin term is crucesignatus. Du Cange renders it as "Qui sacrae Crucis militiae nomen dabant," Thesaurus 2:1175-1176. Compare J. F. Niermeyer, Mediae Latinitatis Lexicon Minus (Leiden: E. J. Brill, 1976), who translates it as "croisé" in French and "crusader" in English. Although it could be argued that, given the terms of the theological discussion in article 2 , a crusader who has taken the vow remains a crusader-designate until he actually completes the crusade, I have kept the term "crusader" throughout. For more on the history and significance of crucesignatus, see Maureen Purcell, Papal Crusading Policy: The Chief Instruments of Papal Crusading Policy and Crusade to the Holy Land from the Final Loss of Jerusalem to 
granting plenary indulgences as part of its strategy for popularizing the crusades. ${ }^{11}$ Admittedly, the exact nature of Pope Urban II's promise at the Council of Clermont (1095) remains a matter of dispute among medieval historians. Nevertheless, the record appears to show that the pontiff promised remission of all penitential practices incurred by the crusaders provided they confess their sins. ${ }^{12}$ In an important study, Maureen Purcell points to a difference between the language allegedly used by Urban II at Clermont, "a full remission of enjoined penance," and the statement by the Fourth Lateran Council in 1215, which promises a "full remission of sin." 13 Either way, we can suppose that a certain confusion between what an indulgence accomplished and what constituted the actual remission of sins enveloped popular views on these matters. ${ }^{14}$

the Fall of Acre, 1244-1291, Studies in the History of Christian Thought 10 (Leiden: E. J. Brill, 1975), p. 5, n. 4; and Michael Markowski, "Crucesignatus: Its Origins and Early Usage," Journal of Medieval History 10 (1984): 157-165.

11. Nikolaus Paulus, Indulgences as a Social Factor, pp. 62ff., includes the crusades among other worthy enterprises that the church promoted through the granting of indulgences. For a comprehensive study of the relationship of indulgences to crusading, see Jonathan Riley-Smith, The First Crusade and the Idea of Crusading (Philadelphia: University of Pennsylvania Press, 1986), especially chapter 1.

12. See Mansi, SCC 20:816. The actual words quoted are "iter pro omni paenitentia reputetur." For a detailed analysis of the documentation concerning Pope Urban's famous speech at Clermont on 27 November 1095, see James A. Brundage, Medieval Canon Law and the Crusader (Madison: University of Wisconsin Press, 1969), pp. 30 ff.

13. Purcell, Papal Crusading Policy, p. 36. For the text of Ad Liberandam Terram Sanctam of Lateran IV, see Antonio García y García, Constitutiones Concilii Quarti Lateranensis Una cum Commentariis Glossatorum, Monumenta Iuris Canonici, series A: Corpus Glossatorum 2 (Vatican City, 1981), pp. 110-118: "plenam suorum concedimus ueniam peccatorum."

14. Generally speaking, before Albert the Great indulgences were considered above all a commutation of poena, but afterwards theologians came to define them as a remission pure and simple. See Albert's Scripta Super Sent. 4.20.E.16: "Dicendum, quod diffinitiones datae satis possunt sustineri. Si quis tamen hanc dare vellet, scilicet quod 'indulgentia sive relaxatio est remissio poenae injunctae ex vi clavium, et thesauro supererogationis perfectorum procedens': puto, quod melius diffiniret." Albert completed this work before 1249 . On the whole question of what indulgences were commonly understood to mean, see Hans Eberhard Mayer, The Crusades, $2 \mathrm{~d}$ ed. (Oxford: Oxford University Press, 1988), pp. 293-295, n. 15. 
Whatever Pope Urban's true intentions may have been, the fact remains that until the thirteenth century, developments in the doctrine of indulgences were almost wholly implicit in theological teaching on the sacrament of penance. By that time, theologians generally understood indulgences as supplying for the satisfactory works that ordinarily form part of the sacramental discipline. In the tertia pars of the Summa theologiae, written shortly after the De quolibet 2, Thomas explains that contrition, confession, and satisfaction are suitably designated as the parts of penance. ${ }^{15}$ Indeed, penitential works such as prayer, fasting, and almsgiving - all of which can serve as works of satisfaction-gradually rectify the disorders of soul that result from a person's sinful actions. Even in his Scriptum on the Sentences, Aquinas introduces his treatment of indulgences towards the end of the tract on the sacrament of penance. ${ }^{16} \mathrm{~A}$ century earlier, however, Peter Lombard had not considered the topic of indulgences important enough to include in the Sentences themselves (1155-1158). Still, the connection among the sacrament of penance, works of satisfaction, and indulgences remains important for appraising correctly the practice of granting indulgences in the thirteenth century.

Since physical participation in a military campaign inevitably involves personal hardships, such an enterprise easily could serve as a sort of satisfaction for sins. Accordingly, medieval inquiry normally included as a matter of course such questions as we find posed in De quolibet 57.2 (held in Paris at Christmastime 1271), "Whether

15. Summa theol. 3.90.2: "Sic igitur requiritur ex parte poenitentis, primo quidem voluntas recompensandi, quod fit per contritionem; secundo quod se subjiciat arbitrio sacerdotis loco Dei, quod fit in confessione; tertio quod recompenset secundum arbitrium ministri Dei, quod fit in satisfactione. Et ideo contritio, confessio et satisfactio ponuntur partes Poenitentiae." In addition, see Poschmann, Der Ablaß, especially pp. $36 \mathrm{ff}$.

16. Scriptum super Sent. 4.20.1 a.3, "Utrum per indulgentiam possit aliquid remitti de poena satisfactoria"; a.4, "Utrum quilibet sacerdos parochialis possit indulgentiam dare"; a.5, "Utrum indulgentia valeat existentibus in peccato mortali." All in all, book 4 devotes nine distinctions to the sacrament of penance. The quaestio unica of the twentieth distinction includes two other articles on the effects of $\sin$ in the life of the believer, namely, a. 1, "Utrum aliquis in extremo vitae suae poenitere possit"; and a. 2, "Utrum poena temporalis, cujus reatus post poenitentiam manet, taxetur secundum quantitatem culpae." For a historical study of indulgences during the early scholastic period, see Nikolaus Paulus, "Die Ablaßlehre der Frühscholastik," Zeitschrift für katholische Theologie 34 (1910): 433ff. 
a crusader who dies on the way to the Holy Land dies in a better state than one who dies on the return trip?" or, in De quolibet 2 8.2 , "Whether a crusader who dies before he can take the journey across the sea has full forgiveness of sins?" Although today such queries may at first seem arcane, they nonetheless facilitate Aquinas's discussion of a range of issues related to Christian satisfaction. For example, he turns again and again to the merits of Christ himself, to the meritorious works of the saints, to the meaning of the thesaurus ecclesiae, to the purpose of satisfaction in the Christian life, and to the conditions that permit a person to gain an indulgence.

The quodlibets report public question-and-answer sessions that took place within medieval universities. At Paris, such quodlibetals were held only during Advent and Lent. Perhaps the exercise was considered penitential for the masters. Palémon Glorieux argues that such unprecedented public discussion first came about at Paris in the mendicants' schools, probably during the student strike of 1220-1231.17 Scholars usually date De quolibet 2 from the beginning of Aquinas's second Parisian regency (1269-1272).18 In the article presently under consideration, Thomas entertains the question whether a crusader who dies before undergoing the hardships of fighting the infidels actually benefits from the crusading indulgence.

Perhaps the question was not purely hypothetical. In fact, the second article may reflect an earnest concern for the French church of the mid-thirteenth century. We know that the French king, Louis IX, came back from his first crusade in 1254. After an unsuccessful campaign, during which he had been imprisoned for about a month, he returned disappointed over the results of his labors. The very next year, Louis had to dispatch a company of royal archers to protect the

17. Palémon Glorieux, La littérature quodlibétique de 1260 à 13201 (Kain: Revue des sciences philosophiques, 1925), 2 (Paris: J. Vrin, 1935), pp. 9-50. For a fuller discussion of Aquinas's use of the quodlibetal questions, see Leonard E. Boyle, "The Quodlibets of St. Thomas and Pastoral Care," Thomist 38 (1974): 232-256, reprinted in his Pastoral Care, Clerical Education, and Canon Law, 1200-1400 (London: Variorum Reprints, 1981), pp. 232-265.

18. The exact dating of the De quolibet $1-12$ remains a matter of dispute among scholars. See Weisheipl, Friar Thomas D'Aquino, pp. 367-368. In "The Quodlibets of St. Thomas," Boyle also gives a summary of the different opinions concerning the dating of the quodlibetal questions. Sandra Edwards follows Weisheipl and Boyle in her Quodlibetal Questions, especially pp. 5-10. 
Dominican convent from the Parisian crowds because they had been turned against the newly arrived mendicants by partisans of the secular masters, who strongly opposed sharing university privileges with the friars. Despite the antagonism generated by established members of the Parisian intellectual community, Louis remained a strong supporter of both the Franciscans and the Dominicans. And, according to William of Tocco, the king especially liked Brother Thomas Aquinas. ${ }^{19}$

Historical evidence lets us suppose that Thomas had his royal patron in mind when responding to the question How does an indulgence affect a man who has not had the chance to endure in his own person the hardship for which the indulgence had been granted. In 1267, with events in the East growing worse for the Christian community, Louis IX once more took the cross. But in little more than a month, after setting sail from Aigues-Mortes in July 1270, the king died in Tunis. Admittedly, one commonly accepted date for De quolibet 2 is Christmastime 1269. Still, scholars recognize that the dating of certain quodlibetal questions remains only probable. For example, Franz Pelster asserts that De quolibet 2 was actually held at Christmastime in 1270.20 Accordingly, this suggestion seems quite reasonable: The fate of the French king had indeed raised interest in the relationship between the remission of punishment and the actual endurance of a stipulated penalty for sin, to the extent that at the very next quodlibetal session, a student might well have posed the question to Magister Thomas Aquinas.

As I have already noted, the plenary indulgence gained prominence in the church's practice as a result of the tactical objective of recovering the Holy Land. The crusading decree of Lateran IV, Ad liberandum (1215), clearly states the cause for receiving the plenary indulgence. Note, however, the exact terms of the decree: the document promises

19. For example, William of Tocco, Hystoria beati Thomae de Aquino, no. 36, records that "de illustri rege Franciae S. Ludovico dicitur, quod semper in rebus arduis dicti Doctoris [scil., Thomae] requirebat consilium, quod frequenter expertus fuerat esse certum: ut utriusque in hoc perpenderetur sanctitas, et illustris regis in dubiis Doctorem consulendum requireret et sancti Doctoris, qui divino doctus Spiritu, quod esset utilius, responderet."

20. Franz Pelster, "Literarische Probleme der Quodlibeta des hl. Thomas von Aquin," Gregorianum 28 (1947): 78-100; and 29 (1948): 62-87, especially pp. 6369. 
full pardon of repented sins properly confessed to "all who in their own person shall undergo this burden [of the Crusade] at their own expense" ("omnibus qui laborem istum in propriis personis subierint et expensis"). 21 This decree, in turn, formed the basis for two subsequent documents, Afflicti corde (Lyons I, 1245) and Zelus fidei (Lyons II, 1274).22 We can assume that Aquinas was aware of the first two decrees. His quodlibetal text acknowledges that a papal letter exists that promises full remission of the punishment due to past sins for those who are willing to undertake the hardships and dangers of a medieval crusade.

\section{THE THEOLOGICAL ARGUMENT}

But what does it mean to affirm that a member of the church obtains a remission of the punishment due to $\sin$ ? How can the church replace punishment for sin with the hardships of a military campaign? And what theological grounds exist for making such a claim within the Christian church? In order to discover Aquinas's answers to these questions, we must now turn to a close examination of his text.

\section{ARGUMENTS}

Aquinas presents four arguments. Two support the thesis that a dead crusader receives the promised indulgence even if he never reached the Holy Land; two others (the so-called sed contra arguments) offer reasons for thinking otherwise. Each of the arguments, of course, supposes the traditional threefold elements of sacramental reconciliation: contritio cordis, confessio oris, satisfactio operis. Judged from one point of view, indulgences constitute commutations of satisfactory works attached to particular deeds, such as prayers, pilgrimages, or other burdensome actions, including the risky and painful undertaking

21. See García y García, Constitutiones, p. 117.

22. See the text in Conciliorum Oecumenicorum Decreta, ed. J. Alberigo et al. (Freiburg: Herder, 1962), pp. 273-277; 285-290. Purcell, Papal Crusading, pp. 187199, also reproduces the decrees of 1245 and 1274. The single extant version of Zelus fidei was first published by H. Fincke, "Constitutiones pro Zelo Fidei," in Konzilienstudien zur Geschichte des 13. Jahrhunderts (Münster, 1891). 
of military combat. Accordingly, the indulgenced deed, the necessary condition of the indulgence, theoretically accomplishes the same good in the sinner that otherwise would have been brought about by the sacramental penance or satisfaction.

The first two arguments represent what we might call the juridical point of view. The first points out that the canonical requirements for'gaining an indulgence have been met once the crusader has fulfilled the stipulated conditions. What are these requirements? The text mentions two: first, the crusader must confess his sins with true contrition; and, second, the indulgence must come from the pope, who alone has jurisdiction over the punishment involved. If these conditions are fulfilled, the suddenly deceased crusader should benefit from the indulgence.

1. For anyone to receive an indulgence, it suffices, as stipulated in the papal letter, that he be truly repentant and that he confess his sins. But a crusader who dies before he leaves for the crusade has fulfilled all those things set forth by the official document in order to receive a plenary indulgence for sins. Therefore he does receive it fully.

2. Furthermore, only God forgives the offense of sin. When the pope, therefore, gives a plenary indulgence, this is not to be referred to the offense but only to the totality of punishments. Now according to the stipulations of the papal document, the one who accepts the crusader's cross will not suffer punishment for his sins. Thus, he will escape punishment immediately, having achieved the full remission of $\sin .{ }^{23}$

These arguments appraise the disorder of sin as something marginal to the psychological capacities of the human person. In order to adjust the punishment due to sin, the church must supply nothing more than the proper legal formality. As a purely legal convention, an indulgence absolves the guilty party from whatever penalty he or she stands liable to suffer.

In other words, the two affirmative arguments simply propose that in order to gain the indulgence, it suffices that a person possess true interior contrition for past sins and have confessed these sins to the priest. Moreover, in accord with the terms of the papal letter, the actual indulgence results from accepting the crusader's cross. In other words, on the assumption that God alone forgives sins (what the Scholastics referred to as culpa), the pope simply grants remission of

23. De quolibet 28.2 ob.1-2 (ed. R. Spiazzi [Turin: Marietti, 1956], pp. 36-37). 
sin's punishment (what the Scholastics called poena) to those willing to accept the burdens of a crusade. The two arguments clearly consider the punishment due to sin as a juridical reality over which the pope holds authority in the same way that an appellate judge can commute the sentence meted out to a convicted prisoner.

The second set of arguments takes up the question from another point of view that reflects the Augustinian teaching on $\sin$ as a deformation of the image of God that remains to some extent even in the baptized. In particular, the second sed contra argument raises the parallel of forgiveness within the sacrament of reconciliation. In the sacrament, the person who confesses and displays sorrow for his or her sins receives absolution from the offense of sin through the ministry of the priest. Still, the tradition also holds that the penitent remains bound to satisfactory works that must be accomplished either during this life or in purgatory. In brief, satisfaction readies one to see God.

1. Augustine says in De Trinitate 15 that to take out the arrow is not the same as to heal the wound. The arrow of sin is removed by the remission of sin; the wound, however, is cured by the restoration of the image [of God], which satisfactory works alone accomplish. But the crusader who dies before he undertakes the actual crusade has undergone nothing for the restoration of the image. Therefore, the wound is not yet healed; and thus he would not enter glory immediately without suffering the punishments of purgatory.

2. Furthermore, any priest uses these words, "I absolve you from all your sins." If therefore the dead crusader escapes all punishment for sin, by the same token anyone who receives absolution from a priest should also. This, however, would be unsuitable. 24

The first of these arguments especially provokes Aquinas to interpret indulgences from what we might nowadays call a personalist standpoint. Since sinful actions disregard the in-built teleologies of human nature, sin affects the psychology and character of the whole person. Only a sort of remedial discipline can redirect human energies towards virtuous activity, that is, fully heal what are described metaphorically as sin's "wounds." Can Aquinas supply a theological explanation that demonstrates why the practice of granting indulgences does not involve an inconsistency with this notion of sin? How does an indulgence respect that sin represents something more

24. De quolibet 28.2 sc.1-2 (ed. Spiazzi, p. 37). 
than the simple infraction of a divine rule or the breach of moral conventions?

As I have explained, a particular theology of sin controls Aquinas's approach to this matter. Sin conforms our psychological powers to purposes that fall short of incarnating God's goodness in the world. Since this sinful deformity implies disordered attachments to created goods, conversion entails satisfactory works. In fact, satisfaction finds its explanation in the human need for reordering our appetites towards morally good objectives instead of bad ones. This alone accomplishes the restoration of the original godly and godward image in the human creature.

The contrary arguments do not suppose that God assigns punishment for sin after the manner of a courtroom proceeding. Rather, the punishment due to $\sin$ arises from the very nature of $\sin$ itself. As Augustine reminds us, the effect of every disordered action remains its own punishment. Appropriately, Thomas cites Augustine's text from De Trinitate 15, "non est idem abstrahere telum, et sanare vulnus." Aquinas interprets this saying to mean that it is one thing to forgive sin (according to the metaphor, to remove the arrow) and another to heal the wounds caused in our human character by sin. This latter process, the restoration of the image of God in the human being, can only come about as a result of spiritual discipline. And Aquinas ascribes this task to works of satisfaction. Now the crusader who dies without performing the equivalent of such satisfaction has not undergone the purgation required to be able to behold the face of God.

Furthermore, the deceased crusader, according to the second argument of this set, does not seem to be in any different position from the ordinary Christian who receives sacramental forgiveness. And it would be unfitting to infer from the case of the unfortunate crusader that satisfaction held no place in the scheme of Christian conversion and renewal. However, if the forgiven sinner or the indulgenced crusader were excused from all of sin's poena, this would imply that the restoration of the image of God occurs without human effort or personal commitment.

\section{THEOLOGICAL PRINCIPLES}

In the body of the text, Aquinas begins to establish the theological basis for granting a commutation of the rectification that 
works of satisfaction ordinarily accomplish in the repentant believer. First Thomas enunciates a basic principle of Christian soteriology, namely, that one person can satisfy for another. Christ accomplished precisely such a work. So Aquinas begins:

For the resolution of this question, it should be noted, as was said above, that the work of one person can be satisfactory for another, whom the doer's intention designates.

But Christ shed his blood for the church, and did and underwent many other things which are to be judged of infinite value by reason of the dignity of [his] person. Thus it is said in Wisdom 7:14 that in it "there is infinite treasure for human beings." Likewise all the other saints had the intention in those things which they suffered and did for God that such would be for the well-being not only of themselves, but for the whole church. ${ }^{25}$

The notion that the quality of the person directly affects the value of whatever sufferings he or she undergoes finds its antecedent in certain provisions of Roman law. Because of the sovereign dignity of Christ's personhood, Christ's work, one can argue, possesses a kind of infinite value. In a way similar to Anselm's argument in Cur Deus homo? Aquinas applies the principle here to account for the universal efficacy of Christ's passion. Or, as the canonical scriptures express it, Christ died "once for all" (Hebrews 7:27).

Aquinas argues next that all Christians can participate in this spiritual good insofar as they form one body in the church. Although the good deeds of the saints possess such a value only insofar as they themselves remain united with Christ, the personal actions of Christ and the saints are said to constitute the thesaurus ecclesiae, the treasury of the church. In order to concretize this notion, however, Aquinas recalls the canon that the one who presides over the universal church on earth possesses authority to dispense this treasury to everyone who remains united in the same bond of charity. In accord with the traditional terminology, Aquinas refers to the authority of the Petrine office as the "power of the keys."

Therefore, dispensation of this treasure belongs to the one who is in charge of the whole church; hence the Lord gave to Peter the keys of the kingdom of heaven [Matthew 16:19]. Accordingly, when either the well-being or absolute necessity of the church requires it, the one who

25. De quolibet 28.2 corp. (ed. Spiazzi, p. 37). 
is in charge of the church can distribute from this unlimited treasure to anyone who through charity belongs to the church as much of the said treasure as shall seem to him opportune, either up to a total remission of punishment or to some certain amount. In this case, the passion of Christ and of the other saints would be imputed to the member as if he himself would have suffered whatever was required for the remission of his sins, as happens when one person satisfies for another, as has already been explained. ${ }^{26}$

The union in charity forms the ultimate ground for the possibility of sharing in the good works associated with Christ and the saints. When Aquinas speaks about imputation, he rather intends the sort of loving communication among the members of the church that forms them as if into one person. ${ }^{27}$ In a certain manner of speaking, indulgences help formalize the participation by one member of the church in the good works of another member.

Accordingly, whether by a total remission, or by only a partial remission, of the punishment due to sin, the beneficiary of an indulgence relies on the sufferings of Christ and of the saints as if having undergone personally the same suffering for sin. As Aquinas puts it in De quolibet 2 7.2, "All who are in charity are like one body, and just as the hand is devoted to the whole body and likewise to any member of the body, so the good of one redounds to all." 28 Aquinas argues that charity, which represents the highest perfection that a human person can achieve, and the ecclesial bond that charity generates are to be considered of greater significance in establishing the grounds for indulgences than the requirements that strict justice would impose.

Now Aquinas can resolve the question of the crusader who dies before he reaches the Holy Land. First, Thomas summarizes the three canonical conditions for receiving an indulgence: (1) the work must involve a cause pertaining to the honor of God or the needs of the

26. De quolibet 28.2 corp. (ed. Spiazzi, p. 37).

27. For instance, see Aquinas's discussion of this point in Summa theol. 3.49.1. Compare Cessario, Godly Image, pp. $159 \mathrm{ff}$.

28. In De quolibet 27.2 , Aquinas is explaining why the prayer of one can benefit another. He affirms that "omnes qui sunt in caritate, sunt quasi unum corpus; et ita bonum unius redundat in omnes, sicut manus deservit toti corpori, et similiter quodlibet corporis membrum." Aquinas refers back to this explanation in the text of 8.2 . 
church; (2) the indulgence must be established by a duly constituted authority; (3) the one who receives the indulgence must already enjoy that union of charity in which the whole reality of the church consists.

For an indulgence to benefit anyone, however, three things are required. First, a cause that appertains to the honor of God, or for the necessity or utility of the church. Secondly, authority in him who grants it: the pope principally, others insofar as they receive either ordinary or commissioned, that is, delegated, power from him. Thirdly, it is required that the one who wishes to receive the indulgence should be in the state of charity. And these three things are designated in the papal letter. For the appropriate cause is designated in that one is sent forth to help the Holy Land; the authority, in that mention is made of the authority of the apostles Peter and Paul, and of the pope himself; charity, in the recipient, in that it is said: "to all truly sorry and confessed." It does not say, "and to those who have satisfied," because the indulgence does not excuse from contrition and confession, but does take the place of satisfaction. ${ }^{29}$

The medieval canonists freely incorporated elements of moral and dogmatic theology into their various efforts to organize the administration of the church. ${ }^{30}$ As the text above makes clear, the canonical outlook governed even such strictly theological topics as divine charity, Christian satisfaction, and the Petrine office.

Second, Aquinas replies to the actual case by insisting on a close reading of the terms given in the papal letter. On the one hand, if the text mentions the actual undertaking of the crusade, as is so in the decrees of 1215 and 1245, then the dead crusader does not gain the indulgence. On the other hand, if the mere intention to go on crusade (votum itineris) constitutes the condition, then the dead crusader has fulfilled what is required.

So, for the question proposed: if according to the provisions of the papal document the indulgence is granted to those taking the cross for a military expedition to the Holy Land, the crusader immediately gains the indulgence, even if he should die before he actually leaves for the crusade. In this case, of course, the condition for the indulgence remains a vow to go and not the actual undertaking itself. If, on the other hand, in the

29. De quolibet 28.2 corp. (ed. Spiazzi, p. 37).

30. For a discussion of poena and culpa in the work of the canonists, see Stephan Kuttner, Kanonistische Schuldlehre, Studi e testi 64 (Vatican City: Biblioteca Apostolica, 1935). 
phrasing of the document it is stipulated that the indulgence should be given to those who actually cross the sea, then the one who dies before he makes the crossing has not fulfilled the condition for the indulgence. ${ }^{31}$

At this point in the discussion, Aquinas establishes that he is conversant with the pertinent canonical legislation and that these legal distinctions play a role in his theological judgment about how indulgences work.

In considering the live crusader, we can easily understand how one who actually endures the hardships of the crusades qualifies for the indulgence. For example, in De quolibet 5 7.2, composed after the text presently under consideration, Aquinas simply affirms that the crusader who dies upon returning from the crusade, all other things being equal, dies with greater merit than he would have done before experiencing the hardships because such a person has personally endured the difficult undertaking. At the same time, Thomas acknowledges that from the point of view of the moral nature of the action, to go on a crusade is more meritorious than merely to return from one. ${ }^{32}$

But Aquinas also undertakes the more difficult case of explaining why the crusader who dies on route to the Holy Land can benefit from the indulgence. How can a merely juridical act, even one issued by the competent authority and fulfilled according to stipulations set down in the papal brief, ready a soul for beatitude? Elsewhere Aquinas explains that the purification of a soul by the punishment of purgatory constitutes nothing else than the expiation of the guilt of punishment required for entering glory. ${ }^{33}$ Given Augustine's presuppositions, the person who has not undertaken such a purification cannot see God because the sinner's personal dispositions remain disproportionate to divine beatitude. But how can an indulgence change our dispositions?

31. De quolibet 28.2 corp. (ed. Spiazzi, p. 37).

32. De quolibet 5 7.2: "Manifestum est autem, quod ille qui moritur in redeundo de ultra mare, ceteris paribus, cum pluribus meritis moritur quam ille qui moritur in eundo: habet enim meritum ex assumptione itineris, et ulterius ex prosecutione, in qua forte multa gravia est passus. Et ideo, ceteris paribus, melius moritur ille qui moritur redeundo; quamvis ire sit magis meritorium quam redire, genus operis considerando."

33. Scriptum super Sent. 4.45.2.2.2 ad 3: "[P]urgatio animae per poenas purgatorii non est aliud quam expiatio reatus impedientis a perceptione gloriae." 
In order to follow Aquinas's reasoning, we need to recall that the general principle for sharing in the spiritual goods of another person differs depending on whether we are talking of merit or of satisfaction. Since merit directly entitles a person to a reward, merit remains incommunicable. On the other hand, the members of the church can share works of satisfaction; just as a person can pay the debts of a friend, so a person can consign satisfaction to another believer. The eminent satisfaction of Christ and the superabundant satisfaction of Mary and the saints form a treasure that the church guards and administers through indulgences: "All the other saints had the intention in those things which they suffered and did for God that such would be for the well-being not only of themselves, but for the whole church." 34 So if the crusader has endured nothing difficult or dangerous, the grounds for allowing him pardon for sin's punishment without his having duly performed penitential activity find their ultimate explanation in the supreme satisfaction that results from Christ's charity.

This explanation develops a theme that Aquinas frequently employs in discussions of Christian redemption. He upholds the principle that one person can satisfy for another. For example, in the Scriptum we find the assertion, "unus pro alio satisfacere potest." 35 In De quolibet 2 7.2, Aquinas further specifies the basis for this sort of interchange: "one is able to satisfy for another, if the former intends this." $36 \mathrm{We}$ now recognize that the metaphor of the treasure graphically symbolizes that the members of the church satisfy for one another. As a result, the church can oversee and regulate the conditions for this exchange. The church indulges those persons who, for whatever reason, have not actually undergone a painful process of spiritual regeneration by themselves. "The reason," writes Aquinas, "why indulgences work remains the unity of the mystical body, in which many perform penitential works beyond the measure of their debts and patiently bear

34. See above, note 25.

35. Scriptum super Sent. 4.20.1.2.3. In this instance, however, St. Thomas makes a distinction between satisfaction and merit. In the latter case, as Summa theol. 12.114.6 clearly teaches, no one can merit grace for someone else in strict equivalence (ex condigno) except Christ alone.

36. De quolibet 2 7.2: "sed secundo modo opus unius valet alteri per modum satisfactionis, prout unus pro altero satisfacere potest, si hoc intendat." 
many unjust treatments, through which a multitude of punishments are able to be expiated." 37 Although the reason remains implicit in the quodlibetal text, Aquinas holds that Christ's love remains powerful enough to alter what the sinner himself did not have the occasion (or perhaps the will) to do for himself.

Accordingly, the satisfaction of Christ remains the principal source of this thesaurus. In the De quolibet 2, Aquinas makes the point that the dignity of Christ's personhood accounts for the exceeding value that his sufferings produced in the church. Of course, this leads us to consider the supreme charity and obedience with which Christ lived his life. In the Summa contra gentiles, for example, we find a complete discussion of these dispositions in Christ. There Thomas explains the universal benefits of Christ's passion by citing the dignity of the person who suffers, "ex dignitate personae patientis," and also by appealing to the charity with which Christ embraced his salvific mission, "ex maiori caritate procedens." 38 Obviously, these affirmations remain crucial for the present discussion.

Aquinas reasons that Christ's heroic love can overcome even the habitual sinner's resistance to godly living. So, the duly indulgenced sinner who dies without undergoing the actual restoration of the divine image is ready for the beatific vision. In another theological opusculum, the Collationes super Pater Noster, Aquinas insinuates a reason to explain why this can happen within the mystical body. He affirms "that the Lord strengthens us against temptation by the fervor of charity, because any charity no matter how small can resist sin." 39 All in all, the incarnation remains the underlying reason

37. Scriptum super Sent. 4.20.1.3: "Ratio autem quare valere possunt, est unitas corporis mystici, in qua multi operibus poenitentiae supererogaverunt ad mensuram debitorum suorum et multas etiam tribulationes injuste sustinuerunt, per quas multitudo poenarum poterat expiari."

38. See Summa contra gentiles 4.55.

39. Collationes super Pater Noster, Petitio 6: "Regit autem hominem ne inducatur in tentationem per fervorem caritatis: quia quaelibet caritas quantumcumque parva, potest resistere cuilibet peccato." Aquinas gave these Lenten sermons in Naples in 1273. Earlier (c. 1270) in the Summa theol. 1-2.114.6, he had made a similar point: "Sed anima Christi mota est a Deo per gratiam, non solum ut ipse perveniret ad gloriam vitae aeternae, sed etiam ut alios in eam adduceret, inquantum est caput Ecclesiae et auctor salutis humanae, secundum illud ad Heb., 'Qui multos filios in gloriam adduxerat, auctorem salutis' etc." 
for our spiritual progress and well-being; and this communication of divine goodness can overcome whatsoever indisposition sin may generate in us.

\section{REPLIES}

According to scholastic practice, the replies to the opening arguments provide Aquinas with an opportunity to supply further clarifications on the topic under discussion. Aquinas addresses each of the four original arguments in turn. The first reply simply asserts the obvious conclusion that a close reading of the stipulations in the papal letter implies. If the condition of the indulgence requires that one actually journey to the Holy land, then, Aquinas rejoins, "it should be pointed out that in this last case, the crusader who dies lacks what is most important for an indulgence, namely, its necessary condition." 40

On the other hand, the reply to the second argument clarifies two distinctions that have emerged in the course of the argument. The first distinction concerns the offense (culpa) of sin and the punishment (poena) that results from sin. The second distinction points out the difference between mediated divine authority, associated with the sacrament of holy orders, and the power of jurisdiction which, according to the customs of the time, even a noncleric may exercise. First of all, Aquinas recalls a basic premise of all sacramental theology: Only God exercises the principal agent's causality in a sacramental action.

To the second: It should be noted that only God possesses the authority to forgive sin's guilt. But mediately it also belongs to the priest, insofar as he offers the sacrament of the forgiveness of sins, for example in baptism or penance. Nevertheless an indulgence does not embrace the forgiveness of sin's guilt, since it is not a sacramental reality; thus it belongs not to order but to jurisdiction. For even a nonpriest can grant an indulgence if he be commissioned to do so. Therefore, the punishment is totally remitted if the condition is fulfilled, not, however, if it is wanting. ${ }^{41}$

Even though other mediators participate in the divine authority, only God can forgive the actual offense of sin; indulgences only 
concern sin's punishment. While from a theological point of view sin's punishment directly affects the character of the believer, a juridical aspect to these punishments still remains. As a theological metaphor, the thesaurus ecclesiae combines this juridical aspect of indulgences with the theological reality of participation in the satisfaction of Christ. Since the church can regulate the juridical punishmentsfor example, in prescribing certain works of satisfaction for particular transgressions-the appropriate persons can establish the conditions for allowing a sinner to benefit from the thesaurus ecclesiae. As we have seen, Aquinas considers it especially fitting that, since the Roman pontiff presides over the universal church, he alone can establish these conditions.

In the reply to the third argument, Aquinas throws still further light on the important distinction between satisfaction as a juridical act and as a theological reality. In this text, we find the clearest expression of the reason why an indulgence can supply for the actual restoration of one whose life has not been reformed by penitential activity. Aquinas's resolution does not depend here simply on technicalities of language in a papal decree. Again, satisfaction can be considered in two ways: as punitive inasmuch as it belongs to retributive justice; and as remedial or healing insofar as it forms part of the sacramental system. Strictly speaking, then, indulgences supply for satisfaction only in its punitive aspect.

To the third: Satisfaction is both punitive, inasmuch as it remains an act of vindicative justice, and restorative, inasmuch as it is in a certain sense sacramental. An indulgence therefore takes the place of satisfaction insofar as it is punitive: because the punishment that another undergoes is imputed to this one as if this one had undergone it, therefore the guilt of punishment is removed. An indulgence does not, however, take the place of satisfaction insofar as it is medicinal, since there still remains the proneness to sinning left from prior sins, the cure of which necessarily entails the work of satisfaction. Accordingly, the crusader, while he lives, should be counseled not to omit satisfactory works, insofar as they serve to guard against repeated sin, even though the guilt of punishment stands totally removed, nor does this require any labor; for the labor of Christ's passion suffices. For one dying, of course, such prevention is not required, only liberation from the guilt of punishment. ${ }^{42}$ 
Clearly, the power of Christ's love works differently in one who is still a member of the church on earth than it does in one who has died. The need for spiritual discipline and reformation of life implies that the first one must continue on as part of the church on earth, for death marks the end of a person's deliberate involvement in the process of salvation. And since the good works of one individual do not appreciate another's spiritual discipline, Aquinas counsels penance even for the individual who does survive the crusade. Even though the successful completion of the indulgenced work replaces the punitive satisfaction, the crusader still needs to do penance for spiritual growth and maturity.

Satisfactory works in the church serve a dual purpose. First of all, since sin results in a state of alienation from God that requires redress on the part of the sinner, satisfaction-which Aquinas construes formally as love and obedience, and materially as bodily sufferingcan restore the relationship. Of course, Aquinas clearly recognizes that the alienation lies in the sinner and not in an injured God. Because the sinner needs to redress the imbalance caused by sinful disorder, theology can still speak about vindicative satisfaction. On the other hand, satisfaction also possesses a therapeutic function. For the sinner willingly undergoes certain exacting exercises that reorder his or her psychological powers towards godly living. Undoubtedly, an indulgence can only satisfy the vindicative aspect of satisfaction. An indulgence cannot assure that the beneficiary receives the benefits of spiritual training in virtuous living. But if someone dies, the spiritual communion of the church insures that the indulgenced soul enjoys passage to the beatific vision without undergoing the ordinary purifications.

The final reply again treats the relationship of an indulgence to the sacramental system. Aquinas has already indicated that satisfaction possesses a certain (quoddam) sacramental power. Thus, he recognizes that theology can only apply in an analogical way the concept of sacrament to satisfaction, and the indulgence that supplies for it. Aquinas restates the principle that the priest mediates God's forgiveness for the offense of sin. While a partial forgiveness for only some sins would impugn the totality of loving communion required by divine charity, sacramental absolution nonetheless leaves some of the punishment due for sin intact. On the other hand, an indulgence can remove all of the punishment for sin, as happens in 
the crusader's indulgence, because of the spiritual authority exercised by the pope.

To the fourth: The words of the priest saying, "I absolve you from all your sins," do not refer to punishment, but to the offense of sin, for which the priestly office authorizes absolution. Now no one can be absolved from one offense without being absolved from all of them. But punishment can be dismissed either totally or partially. For punishment is dismissed partially by sacramental absolution; totally, however, by the spiritual grace of an indulgence: as the Lord himself says [John 8: 11] to the adulterous woman, "I do not condemn you; go, and sin no more." 43

Significantly, in his De regimine principum, Aquinas even identifies this ecclesial authority with the very primacy of Christ's headship over the church. ${ }^{44}$ In this text, Thomas's "personalist" orientation embraces the New Testament teaching on the divine authority which Christ communicates to Peter and his successors.

The citation from John, which brings the article to a conclusion, both intimates Aquinas's evangelical outlook and inspires his procedure in the whole discussion. According to the Gospel account, Jesus speaks to the adulterous woman the words that form the basis for the ministry of reconciliation in the church: "Neither do I condemn you; go, and do not sin again." In Thomas's commentary on this passage of the Gospel, he points out that Christ shows himself to be both a lover of justice and a dispenser of mercy: to be sure, he forgives the woman her sin; however, he also instructs her to use this experience as an opportunity to grow in virtue. ${ }^{45}$ In effect, this reflects Aquinas's principal concern in developing a theology of indulgences. We find a remarkable phrase in the third reply that seems to suggest that indulgenced pardon for $\sin$ is not burdensome because "the labor of Christ's sufferings suffices." In this way, Aquinas brings the discussion

43. De quolibet 28.2 ad 4 (ed. Spiazzi, p. 37-38).

44. De regimine principum 3.10: "Cum enim summus Pontifex sit caput in corpore mystico omnium fidelium Christi, et a capite sit omnis motus et sensus in corpore vero; sic erit in proposito. Propter quod oportet dicere in summo Pontifice esse plenitudinem omnium gratiarum, quia ipse solus confert plenam indulgentiam omnium peccatorum, ut compleat sibi quod de primo principe Domino dicamus, quia de plenitudine eius nos omnes accepimus."

45. See In Joan. 8.1.6: "Sed Dominus culpam non amans, peccatis non favens, ipsam damnavit culpam, non naturam, dicens, 'Amplius noli peccare': ut sic appareat quam dulcis est Dominus per mansuetudinem, et rectus per veritatem." 
back to its proper christological center, which he fully recognizes must ground any theology of indulgences.

This quodlibetal question is a good example of the distinguished theological craftsmanship that Aquinas had achieved by the time he began his second teaching assignment at Paris. The question of penitential satisfaction had occupied theological investigation since the end of the eleventh century, when Anselm finished his celebrated Cur Deus homo? Although some authors slight Thomas's singular achievement in this area, he makes a significant contribution to the transformation and revitalization of the concept of Christian satisfaction.

Aquinas's theology of indulgences clearly represents his seasoned theological insight. In his mature years, he recasts the institution known as indulgences by emphasizing how they form part of the Godman relationship. At the same time, Thomas illustrates the central role that Christ and his intention plays in the actual life of the believer. Aquinas explains all human effort within the church as a result of Christ's capacity to communicate the effects of his own sufferings to his members, "quia sufficit labor passionis Christi." In Aquinas's "personalist" theological perspective, the mystery of God's love draws all men and women to God. Because the church is a communion of charity and belief, indulgences validly express the unity and grace that mark the visible reality of Christ's body. As a matter of fact, Aquinas's teaching on indulgences continues a primitive intuition expressed far earlier by St. Cyprian in his Treatise on the Lord's Prayer:

We do not say "My Father, who art in heaven," nor "Give me this day my daily bread." It is not for oneself alone that each person asks to be forgiven, not to be led into temptation or to be delivered from evil. Rather, we pray in public as a community, and not for one individual but for all. For the people of God are all one. 46

A similar ecclesiological vision undergirds Aquinas's views on indulgences.

Dominican House of Studies, Washington, D.C.

46. De dominica oratione 8 (CSEL 3/1:271). 